\title{
Effect of Potassium Nutrition during Bell Pepper Seed Development on Vivipary and Endogenous Levels of Abscisic Acid (ABA)
}

\author{
Muhammad Marrush, M. Yamaguchi, and M.E. Saltveit ${ }^{1}$ \\ Department of Vegetable Crops, University of California, Davis, CA 95616-8631 \\ AdDitional index words. ABA, Capsicum annuum, fruit ripening, plant growth regulator, seed germination
}

\begin{abstract}
Seeds in fruit of bell pepper (Capsicum annuum 'California Wonder') plants grown in nutrient solutions deficient in potassium $\left(<3 \mathrm{mmol} \cdot \mathrm{L}^{-1}\right)$ showed a higher incidence of sprouting (i.e., vivipary) than seeds in fruit from plants grown at adequate potassium levels $\left(6 \mathrm{mmol} \cdot \mathrm{L}^{-1}\right)$. Tissue analysis showed a progressive drop in the leaf content of potassium with increasing plant maturation for all levels of potassium nutrition. However, potassium in fruit and seeds increased at later stages of maturity. ABA was extracted, isolated and identified from bell pepper seeds obtained from fruit grown under the potassium treatments $\left(0.0,0.6,1.5,3.0\right.$, and $6.0 \mathrm{mmol} \cdot \mathrm{L}^{-1}$ ) at five fruit maturity stages (mature-green to overripe). At early fruit maturity stages, there were no significant differences in seed $A B A$ content in the fruit from the different potassium treatments. However, differences in $A B A$ content and vivipary among the potassium treatments became highly significant as the fruit matured. The concentration of ABA in seeds of potassium-deficient treatments was $\approx 14 \%$ of the control $\left(0.4\right.$ versus $2.8 \mu \mathrm{g}^{-1} \mathrm{~g}^{-1} \mathrm{dry}$ mass $)$. High concentrations of $\mathrm{ABA}$ in bell pepper seeds were associated with low incidence of vivipary and high potassium content in the leaves, fruit and nutrient solution.
\end{abstract}

Seeds of many fleshy fruit, such as tomatoes (Lycopersicon esculentum Mill.) or bell peppers, do not normally germinate as the fruit ripens. However, once the seeds are removed from the fruit, washed and incubated under proper temperature and moisture conditions, germination readily occurs. Sprouting of seeds has been observed in the fruit of the mechanically harvested tomato varieties 'VF 145' and 'VF 13L' while they were still maturing on the plant (Yamaguchi et al., 1967). This physiological disorder, known as vivipary, has also been reported in Chinese cabbage (Brassica pekinensis Rupr.) (Iwata and Eguchi, 1958), bell pepper (Harrington, 1960), and tomato (Dos Santos and Yamaguchi, 1979) when the plants were grown under a potassium deficient regime. Addicott and Lyons (1969) suggested the existence of a correlation between the $\mathrm{ABA}$ content in the fruit flesh and the potential of the seeds to germinate. The contribution of ABA in regulating vivipary has been well established in a number of species (Creelman, 1989; McCarty, 1995).

In addition to $\mathrm{ABA}$, other authors have suggested that the seed coat or water potential may play a decisive role in germination and possibly vivipary of seeds such as tomato and maize (Zea mays L.) (Hilhorst, 1997; McCarty, 1995; Neill et al., 1987). Dos Santos (1974) suggested that potassium nutrition was involved in the incidence of seed sprouting in tomatoes. Also, potassium is reported to mediate many of the complex biochemical reactions in the plant. Lacking sufficient potassium may ultimately alter the levels of different enzymes, organic acids and sugars (Evans and Sorger, 1966), and eventually influence the levels of endogenous hormones.

Environmental stresses, such as drought and water stress (Beardsell and Cohen, 1975; Radin and Ackerson, 1981), waterlogged conditions (Shaybany and Martin, 1977), stressful temperatures (Daie and Campbell, 1981; Raschke et al., 1976), and radiation (Degani and Itai, 1978), influence ABA levels in the plant. However, nutritional stresses and their effects on $\mathrm{ABA}$ have

Received for publication 17 Feb. 1998. Accepted for publication 8 May 1998. The cost of publishing this paper was defrayed in part by the payment of page charges. Under postal regulations, this paper therefore must be hereby marked advertisement solely to indicate this fact.

'To whom reprint requests should be addressed. not been as thoroughly investigated (Daie et al., 1979; Mizrahi et al., 1971; Mizrahi and Richmond, 1972; Radin et al., 1982). In this study, we investigated whether potassium stress influenced the ABA level in developing bell pepper seeds and whether the sprouting of seeds in the maturing bell peppers was correlated with potassium nutrition and potassium content of the leaves and fruit.

\section{Material and Methods}

SAMPLING GREENHOUSE PLANTS GROWN IN POTASSIUM DEFICIENT solutions. Uniform seedlings of bell pepper (Capsicum annuum L. 'California Wonder'), grown under standard cultural practices, were selected and planted in cylindrical polyethylene containers filled with $2.5 \mathrm{~L}$ of complete Hoagland nutrient solution (Lingle and Lorenz, 1969). The solutions in all containers were constantly aerated and changed weekly throughout the experiment. Water lost from the containers was replenished daily with distilled water to maintain a constant level. The initiation of the potassium treatments commenced with the appearance of the first flower cluster. There were five potassium treatments consisting of the following: A) control, potassium at $100 \%$ Hoagland $\left(6 \mathrm{mmol} \cdot \mathrm{L}^{-1}\right.$ potassium $)$, B) potassium at $50 \%$ Hoagland $\left.\left(3 \mathrm{mmol} \cdot \mathrm{L}^{-1}\right), \mathrm{C}\right)$ potassium at $25 \%$ Hoagland $\left(1.5 \mathrm{mmol} \cdot \mathrm{L}^{-1}\right)$, D) potassium at $10 \%$ Hoagland $(0.6$ $\left.\mathrm{mmol} \cdot \mathrm{L}^{-1}\right)$, and $\left.\mathrm{E}\right)$ potassium at $0 \%$ Hoagland $\left(0 \mathrm{mmol} \cdot \mathrm{L}^{-1}\right)$. Each potassium treatment was replicated four times, each individual plant was considered a replication.

Bell peppers were harvested at five maturity stages. The first harvest coincided with the mature-green stage (maturity stage I), the second, 1 week later (maturity stage II), the third at the greenred ripe stage (maturity stage III), the fourth at the mature-red stage (maturity stage IV), and the fifth at the overripe stage when fruit were very soft (maturity stage $V$ ). The fruit and leaf samples were picked at 1-week intervals up to the third maturity stage, and the last two samples were taken at 2-week intervals. On all plants, the fruit sampled for ABA analysis were the five or six that had set first. The leaves sampled were from the vicinity of these fruit. The remaining fruit were collected at the overripe stage (maturity V) and evaluated for seed sprouting. At the time of harvest, the leaves, the fruit flesh and seeds were immediately immersed in liquid nitrogen and later freeze-dried, ground and stored at $-10^{\circ} \mathrm{C}$ until 
Table 1. Effect of potassium treatments on sprouting of seeds in bell peppers harvested at maturity stage V (overripe) during two consecutive years.

\begin{tabular}{|c|c|c|c|c|c|c|c|c|}
\hline \multirow{3}{*}{$\begin{array}{l}\text { Potassium } \\
\text { treatment } \\
\left(\mathrm{mmol} \cdot \mathrm{L}^{-1}\right)\end{array}$} & \multicolumn{2}{|c|}{$\begin{array}{l}\text { Total } \\
\text { fruit } \\
\text { (no.) }\end{array}$} & \multicolumn{2}{|c|}{$\begin{array}{c}\text { Fruit } \\
\text { with sprouted } \\
\text { seeds (no.) }\end{array}$} & \multicolumn{2}{|c|}{$\begin{array}{c}\text { Fruit } \\
\text { with sprouted } \\
\text { seeds }(\%)\end{array}$} & \multicolumn{2}{|c|}{$\begin{array}{l}\text { Sprouted } \\
\text { seed }(\%)\end{array}$} \\
\hline & \multicolumn{6}{|c|}{ Year } & & \\
\hline & 1 & 2 & 1 & 2 & 1 & 2 & 1 & 2 \\
\hline$\overline{\mathrm{A}(6.0)}$ & 94 & 108 & 6 & 5 & 6 & 5 & 8 & 4 \\
\hline B $(3.0)$ & 52 & 69 & 8 & 13 & 15 & 19 & 25 & 20 \\
\hline$C(1.5)$ & 50 & 59 & 20 & 29 & 40 & 49 & 47 & 40 \\
\hline $\mathrm{D}(0.6)$ & 48 & 45 & 25 & 27 & 52 & 60 & 61 & 49 \\
\hline $\mathrm{E}(0.0)$ & 39 & 57 & 24 & 36 & 61 & 63 & 64 & 55 \\
\hline
\end{tabular}

analyzed. The maximum day temperature in the greenhouse ranged from $40^{\circ} \mathrm{C}$ in August to $32^{\circ} \mathrm{C}$ in October, and the minimum night temperature ranged from 20 to $23^{\circ} \mathrm{C}$ for the same period.

Potassium analysis. All leaf, fruit and seed samples were analyzed for potassium. The dried tissue was wet-washed with nitric acid and potassium was determined using an atomic absorption spectrophotometer (model 460; Perkin-Elmer, Norwalk, Conn.).

ABA ANALysis. Only bell pepper seeds were analyzed for ABA content. Peppers from some treatments and maturity stages contained a mixture of sprouted and nonsprouted seeds, while in a few combinations the seeds were either all sprouted (e.g., treatment $\mathrm{E}$ at maturity stage IV) or nonsprouted (e.g., treatment $A$ at maturity stage IV). Freeze-dried, ground seeds ( $\approx 500 \mathrm{mg}$ ) were extracted with $10 \%$ redistilled methyl alcohol for $48 \mathrm{~h}$ under constant shaking at $20^{\circ} \mathrm{C}$. The extract was processed according to the method described by Shaybany and Martin (1977) with slight modifications. This method has a high ABA extraction efficiency. All solvents used in the $\mathrm{ABA}$ extraction procedure were glass distilled twice (Martin et al., 1975). The ethereal-alcoholic solutions of diazomethane for methylation were prepared from Diazald (Aldrich Chemical Co., Milwaukee, Wisconsin). Detection of ABA was carried out on a gas chromatograph (model 5730A; Hewlett-Packard, Wilmington, Del.) equipped with a ${ }^{63} \mathrm{Ni}$ electron capture detector and a spiral glass column $(121.9 \times 0.3 \mathrm{~cm}$ i.d. $)$ packed with $3 \%$ OV-101 over Gas Chrom R 100/120 mesh. Samples $(2 \mu \mathrm{L})$ of methylated seed extract equivalent to $0.5 \mathrm{mg}$ seed dry mass were analyzed isothermally at an oven temperature of $200^{\circ} \mathrm{C}$, with injector port and detector at $250^{\circ} \mathrm{C}$. Peak height was used to quantify the detector response to $\mathrm{ABA}$.

For ABA identification purposes, thin layer chromatography of the final ethyl ether faction, before methylation, was performed on a $20 \times 20-\mathrm{cm}$ plate coated with silica gel GF $23 \mathrm{H}$ (Merck) incorporating an inorganic fluorescent compound. Synthetic ABA cis-trans isomer (Sigma Chemical Co.) markers and the ether fraction from bell pepper seed extracts were applied to the plates and allowed to develop in n-butanol, n-propanol, $0.88 \mathrm{~N}$ ammonium hydroxide, water solution (v/v, 2:6:1:2). After development, the plates were examined under a longwave ultraviolet (UV) lamp and the UV absorbing bands were marked. Rf values for the extracts and authentic ABA were calculated and compared. Further identification of the ABA extracted from bell pepper seeds involved coinjection of the methylated seed extract and methylated authentic cis-trans ABA into the gas chromatograph (Browning et al., 1970).

STatistics. The experimental design was completely randomized with five levels of potassium, and four replications. Experiments were conducted during 2 consecutive years and repeated with similar results. Data were collected and subjected to statistical analysis. All of the data presented in Tables 2 to 5 were compared horizontally and vertically by using Duncan's multiple range test for significance $(P<0.05)$.

\section{Results and Discussion}

INFLUENCE OF POTASSIUM NUTRITION ON VIVIPARY IN BELL PEPPERS. The percentage of sprouted seeds and of fruit containing sprouted seeds increased with decreasing potassium concentrations in bell pepper plants grown in nutrient solutions with normal to deficient potassium levels (Table 1). Increasing vivipary was also observed in fruit of greenhouse grown tomato (VF-145) plants when they were supplied with deficient amounts of potassium and boron (Dos Santos and Yamaguchi, 1979). Seeds also sprouted in fruit from bell pepper plants grown in nutrient solution lacking potassium (Harrington, 1960). Harrington (1960) proposed that potassium may be necessary for the formation of a germination-

Table 2. Potassium content of bell pepper lcaves with respect to fruit maturity and potassium nutrition.

\begin{tabular}{|c|c|c|c|c|c|c|}
\hline \multirow{2}{*}{$\begin{array}{l}\text { Potassium } \\
\text { treatment } \\
\left(\mathrm{mmol} \cdot \mathrm{L}^{-1}\right)\end{array}$} & \multicolumn{6}{|c|}{ Fruit maturity stage } \\
\hline & I & II & III & IV & $\mathrm{V}$ & Avg \\
\hline & \multicolumn{6}{|c|}{ Dry mass (\%) } \\
\hline $\mathrm{A}(6.0)$ & $5.21 \mathrm{a}^{y} \mathrm{u}^{\mathrm{x}}$ & $4.89 \mathrm{~b} \mathrm{u}$ & $4.23 \mathrm{cu}$ & $3.84 \mathrm{du}$ & $3.59 \mathrm{e} \mathrm{u}$ & 4.34 \\
\hline B (3.0) & $4.59 \mathrm{ar}$ & $3.75 \mathrm{bv}$ & $2.96 \mathrm{cv}$ & $2.56 \mathrm{dv}$ & $2.17 \mathrm{e} \mathrm{v}$ & 3.21 \\
\hline$C(1.5)$ & $3.52 \mathrm{a} \mathrm{w}$ & $2.44 \mathrm{bw}$ & $2.06 \mathrm{c} \mathrm{w}$ & $1.73 \mathrm{~d} \mathrm{w}$ & $1.15 \mathrm{ew}$ & 2.18 \\
\hline $\mathrm{D}(0.6)$ & $3.02 \mathrm{ax}$ & $1.90 \mathrm{bx}$ & $1.52 \mathrm{cx}$ & $1.16 \mathrm{~d} x$ & $0.83 \mathrm{ex}$ & 1.69 \\
\hline $\mathrm{E}(0.0)$ & $2.51 \mathrm{ay}$ & 1.17 b y & $1.19 \mathrm{~b} \mathrm{y}$ & $0.94 \mathrm{cy}$ & $0.64 \mathrm{dy}$ & 1.29 \\
\hline Average & 3.77 & 2.83 & 2.39 & 2.05 & 1.68 & 2.54 \\
\hline
\end{tabular}

${ }^{7}$ Average of eight observations (two $\times$ four replications).

${ }^{y}$ Test of significance for horizontal comparison, unlike letters are significantly different at $5 \%$ level (Duncan's multiple range test).

'Test of significance for vertical comparison, unlike letters are significantly different at $5 \%$ level (Duncan's multiple range test). 
Table 3. Potassium content of bell peppers with respect to fruit maturity and potassium nutrition.

\begin{tabular}{|c|c|c|c|c|c|c|}
\hline \multirow{2}{*}{$\begin{array}{l}\text { Potassium } \\
\text { treatment } \\
\left(\mathrm{mmol} \cdot \mathrm{L}^{-1}\right)\end{array}$} & \multicolumn{6}{|c|}{ Fruit maturity stage ${ }^{2}$} \\
\hline & I & II & III & IV & $\mathrm{V}$ & Avg \\
\hline & \multicolumn{6}{|c|}{ Dry mass (\%) } \\
\hline $\mathrm{A}(6.0)$ & $2.54 b^{y} u^{x}$ & $2.36 \mathrm{du}$ & $2.09 \mathrm{eu}$ & $2.42 \mathrm{c} \mathrm{u}$ & $2.73 \mathrm{au}$ & 2.43 \\
\hline $\mathrm{B}(3.0)$ & $1.96 \mathrm{~d} \mathrm{w}$ & $2.12 \mathrm{c} \mathrm{v}$ & $2.13 \mathrm{c} \mathrm{u}$ & $2.28 \mathrm{~b} \mathrm{w}$ & 2.38 a x & 2.17 \\
\hline $\mathrm{C}(1.5)$ & $1.95 \mathrm{~d} \mathrm{w}$ & $2.04 \mathrm{c} \mathrm{w}$ & $1.82 \mathrm{e} \mathrm{v}$ & $2.17 \mathrm{~b} \mathrm{x}$ & 2.31 a y & 2.06 \\
\hline $\mathrm{D}(0.6)$ & $2.04 \mathrm{~b} \mathrm{v}$ & $1.87 \mathrm{cx}$ & $2.08 \mathrm{~b} \mathrm{u}$ & $2.08 \mathrm{~b} \mathrm{y}$ & 2.57 av & 2.13 \\
\hline $\mathrm{E}(0.0)$ & $1.94 \mathrm{~d} \mathrm{w}$ & $1.85 \mathrm{e} \mathrm{x}$ & $2.08 \mathrm{c} \mathrm{u}$ & $2.35 \mathrm{bv}$ & $2.46 \mathrm{aw}$ & 2.14 \\
\hline Average & 2.09 & 2.05 & 2.04 & 2.26 & 2.49 & 2.19 \\
\hline
\end{tabular}

${ }^{\mathrm{z}}$ Average of eight observations (two $\times$ four replications).

y Test of significance for horizontal comparison, unlike letters are significantly different at $5 \%$ level (Duncan's multiple range test).

${ }^{x}$ Test of significance for vertical comparison, unlike letters are significantly different at $5 \%$ level (Duncan's multiple range test).

inhibiting compound, or it may be that potassium deficiency brings about formation of a substance promoting germination.

Nitrogen fertilization has also been associated with vivipary of tomatoes. In field fertility plots, high nitrogen treatments and high temperatures induced similar trends in the expression of vivipary in 'VF145' tomatoes (Yamaguchi et al., 1967). It appears that the ripeness of the fruit is also important since sprouted seeds, in either tomatoes or bell peppers, have only been noted in ripe (maturity IV) to overripe (maturity V) fruit (Dos Santos and Yamaguchi, 1979; Harrington, 1960; Yamaguchi et al., 1967).

Deficiencies in potassium may have many different in vivo effects confirming that potassium functions in several different metabolic processes (Evans and Sorger, 1966). A multiplicity of enzyme systems requiring potassium (Sodek et al., 1980) or situations where other cations stimulated (Lau and Yang, 1976a) or inhibited (Lau and Yang, 1976b) the production of ethylene have been observed. A deficiency of potassium or other cations, therefore, would be expected to result in the malfunction of a whole series of metabolic processes, among which could be the synthesis and metabolism of $\mathrm{ABA}$ and other plant growth regulators (McCarty, 1995).

Potassium content in THe leaves, Fruit, AND SEeds of Bell PEPPER. The potassium contents of leaves, fruit, and seeds are presented in Tables 2, 3, and 4, respectively. At the first sampling date (fruit maturity stage I), leaf potassium was the highest for all potassium treatments, and then decreased for the remainder of the sampling period (Table 2). On the other hand, fruit potassium increased significantly at maturity stage $V$ for all treatments (Table 3). Seed potassium was not affected drastically by any of the treatments and remained more or less constant throughout the sampling period (Table 4).
Pepper plants in treatments A and B showed no signs of potassium deficiency, while plants in treatment $C$ started showing some leaf bronzing and mottling at fruit maturity stage III. Plants in treatments $\mathrm{D}$ and $\mathrm{E}$ showed early symptoms of potassium deficiency at fruit maturity stage II and became worse as the season progressed until they were completely necrotic at the end of the experiment.

The potassium levels we observed in the different tissues of bell pepper, are in agreement with other reports (Burdine et al, 1962; Lingle and Lorenz, 1969; Maynard et al., 1980; Miller et al., 1979). Physiologically, potassium is readily translocated throughout the plant. Since developing fruit and seeds are major sinks during plant growth, potassium was probably translocated to these sites at the expense of other plant tissues, explaining why low potassium treatments produced seeds sufficient in potassium, even though seed yield was reduced because of poor plant growth.

ABA CONTENT IN BeLL PEPPER SEeds. The endogenous ABA content in seeds from bell peppers at maturity stages IV and $V$ were significantly higher in treatments $A$ and B, changed insignificantly in $\mathrm{C}$, and were significantly lower in $\mathrm{D}$ and $\mathrm{E}$ at maturity stage IV (Table 5). It is relevant to mention that maturity stages IV and V coincided with the appearance of seed sprouting inside bell peppers. No sprouting was detected in fruit collected from stages I, II, and III. However, in general, low potassium treatments showed the highest incidence and intensity of vivipary (Table 1) and exhibited the lowest seed ABA content (Table 5), especially at maturity stages IV and V when the fruit were mature-red or overripe.'

Entirely sprouted seed samples obtained from treatment $E$ at maturity state IV (Table 5), contained ABA at $0.4 \pm 0.2 \mu \mathrm{g} \cdot \mathrm{g}^{-1}$ dry mass. At the other extreme, normal nonsprouting seed samples, obtained from treatment A at maturity stage IV (Table 5), con-

Table 4. Potassium content of bell pepper seeds with respect to fruit maturity and potassium nutrition.

\begin{tabular}{|c|c|c|c|c|c|c|}
\hline \multirow{2}{*}{$\begin{array}{l}\text { Potassium } \\
\text { treatment } \\
\left(\mathrm{mmol} \cdot \mathrm{L}^{-1}\right)\end{array}$} & \multicolumn{6}{|c|}{ Fruit maturity stage ${ }^{\mathrm{z}}$} \\
\hline & I & II & III & IV & $\mathrm{V}$ & Avg \\
\hline & \multicolumn{6}{|c|}{ Dry mass (\%) } \\
\hline $\mathrm{A}(6.0)$ & $2.76 a^{y} u^{x}$ & $2.58 \mathrm{~b} \mathrm{u}$ & $2.55 \mathrm{bu}$ & $2.15 \mathrm{du}$ & $2.42 \mathrm{cu}$ & 2.49 \\
\hline $\mathrm{B}(3.0)$ & $2.30 \mathrm{av}$ & $1.98 \mathrm{~d} \mathrm{v}$ & $2.07 \mathrm{cv}$ & $2.18 \mathrm{~b} \mathrm{u}$ & $2.01 \mathrm{dx}$ & 2.11 \\
\hline $\mathrm{C}(1.5)$ & $2.21 \mathrm{aw}$ & $1.98 \mathrm{c} \mathrm{v}$ & $1.79 \mathrm{dx}$ & $2.04 \mathrm{~b} \mathrm{v}$ & $1.97 \mathrm{cx}$ & 2.00 \\
\hline $\mathrm{D}(0.6)$ & $2.02 \mathrm{ax}$ & $1.70 \mathrm{c} \mathrm{w}$ & $1.81 \mathrm{bx}$ & $1.82 \mathrm{bw}$ & $2.06 \mathrm{a} \mathrm{w}$ & 1.88 \\
\hline $\mathrm{E}(0.0)$ & $1.98 \mathrm{bx}$ & $1.95 \mathrm{bv}$ & $1.94 \mathrm{bw}$ & $2.14 \mathrm{a} \mathrm{u}$ & $2.11 \mathrm{av}$ & 2.03 \\
\hline Average & 2.25 & 2.04 & 2.03 & 2.07 & 2.11 & 2.10 \\
\hline
\end{tabular}

${ }^{\mathrm{z}}$ Average of eight observations (two $x$ four replications).

${ }^{y}$ Test of significance for horizontal comparison, unlike letters are significantly different at $5 \%$ level (Duncan's multiple range test).

'Test of significance for vertical comparison, unlike letters are significantly different at $5 \%$ level (Duncan's multiple range test). 
Table 5. Abscisic acid content of bell pepper seeds with respect to fruit maturity and potassium nutrition.

\begin{tabular}{|c|c|c|c|c|c|c|}
\hline \multirow{2}{*}{$\begin{array}{l}\text { Potassium } \\
\text { treatment } \\
\left(\mathrm{mmol} \cdot \mathrm{L}^{-1}\right)\end{array}$} & \multicolumn{6}{|c|}{ Fruit maturity stage } \\
\hline & I & II & III & IV & $\mathrm{V}$ & Avg \\
\hline & \multicolumn{6}{|c|}{ Dry mass $\left(\mu \mathrm{g} \cdot \mathrm{g}^{-1}\right)$} \\
\hline $\mathrm{A}(6.0)$ & $1.2 c^{y} v^{x}$ & $1.1 \mathrm{~cd} \mathrm{u}$ & $1.0 \mathrm{~d} \mathrm{w}$ & $2.8 \mathrm{a} \mathrm{u}$ & $2.3 \mathrm{bu}$ & 1.7 \\
\hline $\mathrm{B}(3.0)$ & $1.3 \mathrm{buv}$ & $1.1 \mathrm{bcd} \mathrm{u}$ & $0.9 \mathrm{~d} \mathrm{u}$ & $1.5 \mathrm{av}$ & $1.3 \mathrm{bc} \mathrm{v}$ & 1.2 \\
\hline $\mathrm{C}(1.5)$ & $1.1 \mathrm{ab} \mathrm{w}$ & $1.2 \mathrm{a} \mathrm{u}$ & $0.9 \mathrm{~b} \mathrm{u}$ & $0.9 \mathrm{~b} \mathrm{w}$ & $1.1 \mathrm{ab} \mathrm{w}$ & 1.0 \\
\hline $\mathrm{D}(0.6)$ & $1.5 \mathrm{a} \mathrm{u}$ & $1.3 \mathrm{au}$ & $0.9 \mathrm{bu}$ & $0.6 \mathrm{cx}$ & $0.8 \mathrm{bcx}$ & 1.0 \\
\hline$E(0.0)$ & $1.0 \mathrm{a} \mathrm{w}$ & $1.2 \mathrm{a} \mathrm{u}$ & $0.8 \mathrm{bu}$ & $0.4 \mathrm{cx}$ & $0.5 \mathrm{c} \mathrm{x}$ & 0.8 \\
\hline Average & 1.2 & 1.2 & 0.9 & 1.3 & 1.2 & 1.2 \\
\hline
\end{tabular}

${ }^{\mathrm{z}}$ Average of eight observations (two $\times$ four replications).

yTest of significance for horizontal comparison, unlike letters are significantly different at $5 \%$ level (Duncan's multiple range test).

xTest of significance for vertical comparison, unlike letters are significantly different at $5 \%$ level (Duncan's multiple range test).

tained $\mathrm{ABA}$ at $2.8 \pm 0.2 \mu \mathrm{g} \cdot \mathrm{g}^{-1}$ dry mass.

If the potassium nutrition of the bell pepper plant is influencing vivipary, then there should be a high correlation between the potassium treatments and the potassium content of the plant, between the potassium treatments and the $\mathrm{ABA}$ content of the seeds, and therefore between the potassium content of the plant and the ABA content of the seeds. There was not a consistent nor high correlation between the potassium treatments and the potassium content of bell peppers (Table 3 ) or seeds (Table 4). However, there was a good correlation between the potassium treatments and leaf potassium content for all maturities (Table 2) and between the potassium treatments and seed ABA content for maturities IV and $\mathrm{V}$ (Table 5). The relation between the concentration of potassium in leaves of plants with mature stage III, IV and V fruit (Table 2) and the concentration of ABA in seeds of these plants (Table 5) is given by the following equations: Maturity III: Seed ABA $\left(\mu \mathrm{g} \cdot \mathrm{g}^{-}\right.$ $\left.{ }^{1}\right)=0.78+[$ leaf potassium (\% dry mass) $\times 0.0505]$ with an $r^{2}$ of 0.77 ; Maturity IV: Seed ABA $\left(\mu \mathrm{g} \cdot \mathrm{g}^{-1}\right)=-0.42+[$ leaf potassium $(\%$ dry mass $) \times 0.81]$ with an $r^{2}$ of 0.99 ; Maturity V: Seed ABA $\left(\mu \mathrm{g} \cdot \mathrm{g}^{-}\right.$ $\left.{ }^{1}\right)=0.28+[$ leaf potassium (\% dry mass) $\times 0.55]$ with an $r^{2}$ of 0.95 (Fig. 1). The correlation coefficient $(0.77)$ and the slope $(0.05)$ are both much lower for maturity III than for maturity IV (0.99 and $0.81)$ or maturity $\mathrm{V}(0.95$ and 0.55$)$. The slope for maturity stages I, II, and III were $0.03,0.04$, and 0.05 , respectively, showing that there was very little effect of leaf potassium on seed ABA content at these stages of fruit maturity. It appears that potassium deficiency only had a really significant effect on seed ABA content when the fruit had reached maturity stages IV or V.

ABA AND VIVIPARY. A number of studies have correlated vivipary with ABA levels in the seed (Creelman, 1989; Groot and Karssen, 1992; Hendrix and Radin, 1984; Neill et al., 1986; Smith et al., 1993). Some have tried to determine if vivipary could be related to a deficiency of ABA in mutant seeds. The controlling affect of ABA on vivipary is supported by the observation that most viviparous mutants of maize affect abscisic acid biosynthesis (Smith at al., 1993). Seedlings grown from grains of most viviparous maize lines contained $6 \%$ to $16 \%$ of the wild-type level of ABA (Neill et al., 1986). Other studies with viviparous mutants and regulation of gene expression during seed maturation in maize and Arabidopsis thaliana have shown that vivipary is not only controlled by the level of ABA in the seed, but also by the sensitivity of the seed to ABA (Hattori, 1993; Robichaud and Sussex, 1986).
Yet there is some evidence that even in the absence of normal levels of ABA, gibberellins are required to stimulate the developmental program leading to vivipary in maize (White et al., 1996).

The rise of $A B A$ in treatment $A$ (Table 5), and to a certain degree in treatment $B$ during the later stages of growth, and its apparent effect on influencing the expression of vivipary were also observed in other crops. Studying the changing patterns of ABA in developing wheat grains, King (1976) reported that germination capacity of isolated embryos and whole grains declined as ABA accumulated. Abscisic acid-deficient mutant tomato seeds exhibited viviparous germination in overripe fruit (Groot and Karssen, 1992). Crosses between mutant and wild type and self pollination of heterozygous plants showed that, in particular, the ABA fraction of embryo and endosperm is decisive for the induction of dormancy. They hypothesized that the high ABA concentrations that occur during seed development in wild-type seeds prevented vivipary by inhibiting cell elongation in the radicle.

Import of ABA into the bell pepper seed could account for its pattern of increase to maturity. Certainly, ABA is transported in plants in the phloem and xylem (Lenton et al., 1968). In addition, ABA may be synthesized in the seed (McCarty, 1995; Milborrow and Robinson, 1973). Furthermore, not all the ABA found in other growing organs is imported. ABA accumulation associated with

Fig. 1. Relation between the concentration of potassium in the leaf and the concentration of ABA in the seed of fruit at maturity stages III, IV, and V.

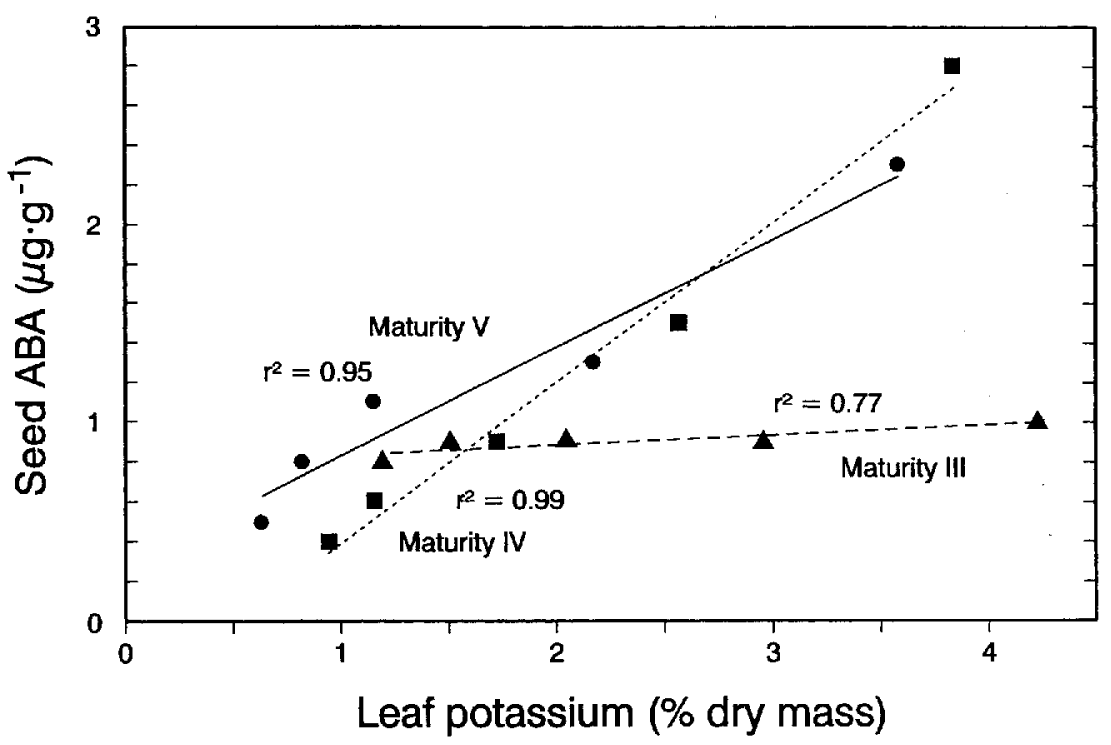

J. Amer. Soc. Hort. ScI. 123(5):925-930. 1998. 


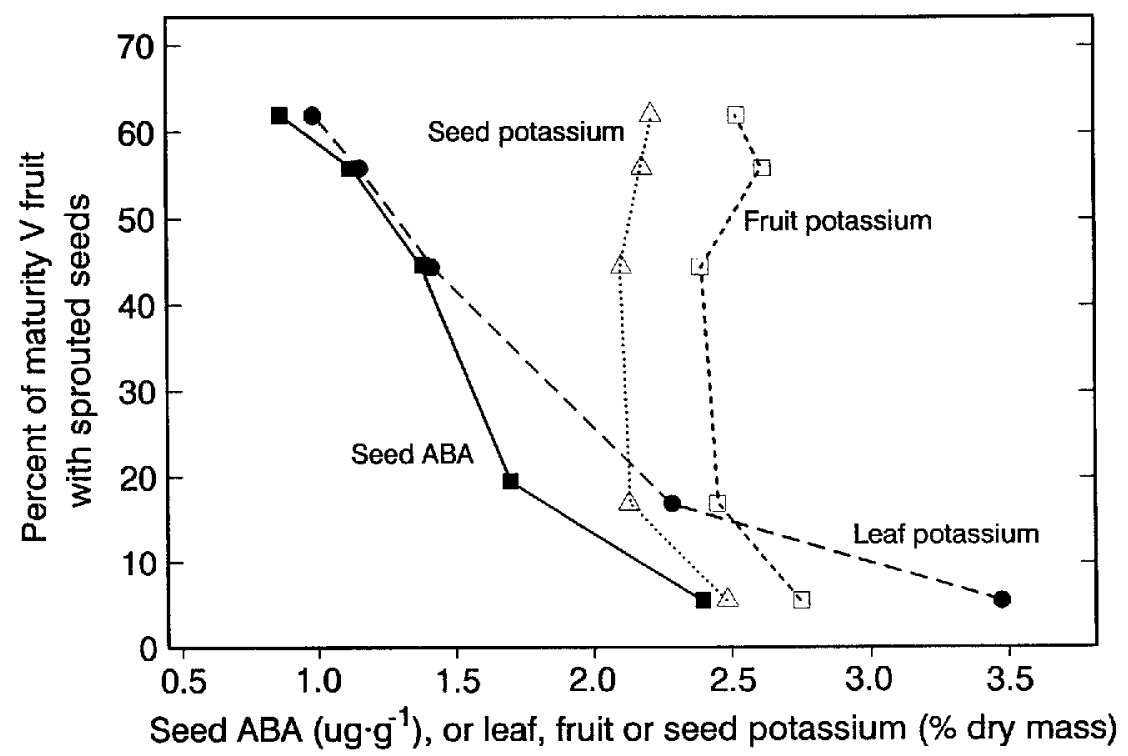

Fig. 2. Relation between the level of ABA in the seed, or the level of potassium in the leaf, fruit or seed and the percent of fruit at maturity stage $\mathrm{V}$ with sprouted seeds.

maturation of tomato fruit was reported to occur equally well in attached and detached fruit (Dos Santos, 1974).

The potassium treatments had little effect on the potassium content of fruit (Table 3) or seeds (Table 4) at maturity stage $V$ and, therefore, fruit and seed potassium levels had little affect on vivipary (Fig. 2). In contrast, leaf potassium content (Table 2) and seed ABA content (Table 5) were greatly affected by the potassium treatments, especially after maturity stage IV (Table 5), and both had a pronounced affect on vivipary (Fig. 2). The correlation between leaf potassium content and the percent of fruit at maturity stage $\mathrm{V}$ with sprouted seeds was very high for leaves collected adjacent to maturity IV fruit $\left(r^{2}=0.95\right)$ and maturity $\mathrm{V}$ fruit $\left(r^{2}=\right.$ 0.93 ), and are given by the following equations: Maturity IV: percent fruit with sprouted seeds $=78.6$ - [leaf potassium ( $\%$ dry mass) $\times 20.3$ ]; Maturity V: percent fruit with sprouted seeds $=69.6$ - [leaf potassium (\% dry mass) $\times 19.4$ ]. In contrast, the correlation between seed ABA content and the percent of fruit with sprouted seeds was lower for maturity IV $\left(r^{2}=0.89\right)$ and maturity $\mathrm{V}\left(r^{2}=\right.$ 0.85 ). The corresponding equation are; Maturity IV: percent fruit with sprouted seeds $=66.9-\left[\right.$ seed ABA $\left(\mu g \cdot \mathrm{g}^{-1}\right.$ dry mass $\left.) \times 24.1\right]$; Maturity V: percent fruit with sprouted seeds $=76.9-[$ seed ABA $\left(\mu \mathrm{g} \cdot \mathrm{g}^{-1}\right.$ dry mass $\left.) \times 33.2\right]$. While seed ABA levels and vivipary are still significantly related, the higher correlation between leaf potassium levels and vivipary $\left(r^{2}=0.95\right.$ and 0.93 for maturity IV and V) than between seed ABA content and vivipary $\left(r^{2}=0.89\right.$ and 0.85 for maturity IV and V) suggests that potassium nutrition may be having more of an affect on vivipary than by simply altering ABA levels in the seed.

The detection of low seed ABA levels in the maturing seeds of the low potassium treatments requires further examination. Low levels of ABA could be explained simply as a cessation of ABA import and synthesis coupled with continuous degradation. Premature drying of isolated wheat (Triticum aestivum) grain led to $\mathrm{ABA}$ loss and during the same time identical grain kept moist contained four times as much ABA (King, 1976). Thus, a role for ABA in seed maturation and prevention of premature seed sprouting could be suggested. Moreover, ABA was also suggested to inhibit precocious embryo germination and premature production of enzymes specifically associated with germination in developing cotton (Gossypium hirsutum) bolls (Hendrix and Radin, 1984; Ihle and Dure, 1972; Kriz et al., 1990) and pea (Pisum sativum) seeds (Yomo and Varner, 1973). Unfortunately, simultaneous measurements of ABA and germination have not generally been available.

From the data presented and the previous discussion, it seems reasonable to conclude that bell pepper seed maturation and premature germination (i.e., vivipary) are significantly influenced by the effect of potassium nutrition on leaf potassium content and endogenous levels of the plant growth regulator $\mathrm{ABA}$.

\section{Literature Cited}

Addicott, F.T. and J.L. Lyons. 1969. Physiology of abscisic acid and related substances. Annu. Rev. Plant Physiol. 20:139-164.

Beardsell, M.F. and D. Cohen. 1975. Relationships between leaf water status, abscisic acid levels, and stomatal resistance in maize and sorghum. Plant Physiol. 56:207-12.

Browning,. G., G.V. Hood, and P. Gaskin. 1970. Identification of abscisic acid in flower buds of Coffea arabica L. Planta 94:213-219.

Burdine, H.W., V.L. Guzman, and C.C. Fortenstine. 1962. Phosphorus and potassium fertilization of pepper and sweet corn. Fla. Agr. Expt. Sta. Annu. Rpt. p. 243.

Creelman, R.A. 1989. Abscisic acid physiology and biosynthesis in higher plants. Physiol. Plant. 75:131-136.

Daie, J. and W.F. Campbell. 1981. Response of tomato plants to stressful temperatures. Plant Physiol. 67:26-29.

Daie, J., S.D. Seeley, and W.F. Campbell. 1979. Nitrogen deficiency influence on ABA in tomato. HortScience 14:261-262.

Degani, N. and C. Itai. 1978. The effect of radiation on growth and abscisic acid in wheat seedlings. Environ. Expt. Bot. 18:113-115.

Dos Santos, D. 1974. Seed sprouting in the tomato fruit. PhD thesis. Univ. Calif., Davis. p. 94.

Dos Santos, D. and M. Yamaguchi. 1979. Seed sprouting in tomato fruits. Scientia Hort. 11:131-9.

Evans, H.J. and G.J. Sorger. 1966. Role of mineral elements with emphasis on the univalent cations. Annu. Rev. Plant Physiol. 17:47-76.

Groot, S.P.C. and C.M. Karssen. 1992. Dormancy and germination of abscisic acid-deficient tomato seeds. Studies with the sitiens mutant. Plant Physiol. 99:952-958.

Harrington, J.F. 1960. Germination of seeds from carrot, lettuce and pepper plants grown under severe nutrient deficiencies. Hilgardia 30:219235.

Hattori, T. 1993. Viviparous mutants and regulation of gene expression during seed maturation. Chem. Reg. Plants 28:23-32.

Hendrix, D.L. and J.W. Radin. 1984. Seed development in cotton: Feasibility of a hormonal role for abscisic acid in controlling vivipary. J. Plant Physiol. 117:211-221.

Hilhorst, H.W.M. 1997. Primary dormancy in tomato. Further studies with the sitiens mutant. Basic and applied aspects of seed biology. In: R.H. Ellis, M. Black, A.J. Murdoch, and T.D. Hong (eds.). Proc. 5th Intl. Wkshp. Seeds. Current Plant Sci. Biotechnol. Agr. 30:191-201.

Ihle, J.N. and L.S. Dure. 1972. The temporal separation of transcription and translation and its control in cotton embryoenesis and germination, p. 216-221. In: D.T. Carr (ed.). Plant growth substances. Springer, New York.

Iwata, M. and Y. Eguchi. 1958. Effects of phospborus and potassium supplied for the various stages of growth, on the yield and quality of seeds of Chinese cabbage. J. Hort. Assn. Jpn. 27:171-178 (in Japanese with English summary).

King, R.W. 1976. Abscisic acid in developing wheat grains and its relationship to grain growth and maturation. Planta (Berl.) 132:43-51. Kriz, A.R., M.S. Wallace, and R. Paiva. 1990. Globulin gene expression 
in embryos of maize viviparous mutants. Evidence for regulation of the Glb1 gene by ABA. Plant Physiol. 92:538-542.

Lau, O.L. and S.F. Yang. 1976a. Stimulation of ethylene production in the mung bean hypocotyls by cupric ion, calcium ion, and kinetin. Plant Physiol. 57:88-92.

Lau, O.L. and S.F. Yang. 1976b. Inhibition of ethylene production by cobaltous ion. Plant Physiol. 58:114-117.

Lenton, J.R., M.R. Bowen, and P.F. Saunders. 1968. Detection of abscisic acid in the xylem sap of willow (Salix viminalig L.) by gas liquid chromatography. Nature 220:86-87.

Lingle, J.C. and O.A. Lorenz. 1969. Potassium nutrition of tomatoes. J. Amer. Soc. Hort. Sci. 94:679-683.

McCarty, D.R. 1995. Genetic control and integration of maturation and germination pathways in seed development. Annu. Rev. Plant Physiol. Plant Mol. Biol. 46:71-93

Martin, G.C., F.G. Dennis, P. Gaskir, and J. MacMillan. 1975. Contaminants present in materials commonly used to purify plant extracts for hormone analysis. HortScience 10:598-599.

Maynard, D.N., O.A. Lorenz, and V. Magnifico. 1980. Growth and potassium partitioning in tomato. J. Amer. Soc. Hort. Sci. 105:79-82

Milborrow, B.V. and D.R. Robinson. 1973. Factors affecting the biosynthesis of abscisic acid. J. Expt. Bot. 24:537-548.

Miller, C.H., R.E. McCollum, and S. Claimon. 1979. Relationship between growth of bell peppers (Capsicum annuum $\mathrm{L}_{\text {, }}$ ) and nutrient accumulations during ontogeny in field environments. J. Amer. Soc. Hort. Sci. 104:852-857.

Mizrahi, Y., A. Blumenfeld, S. Bittner, and A.E. Richmond. 1971. Abscisic acid and cytokinin contents of leaves in relation to salinity and relative humidity. Plant Physiol. 48:752-755.

Mizrahi, Y. and A.E. Richmond. 1972. Abscisic acid in relation to mineral deprivation. Plant Physiol. 50:667-670.

Neill, S.J., R. Horgan, and A.D. Parry. 1986. The carotenoid and abscisic acid content of viviparous kernels and seedlings of Zea mays L. Planta. 169:87-96.
Neill, S.J., R. Horgan, and A.F. Rees. 1987. Seed development and vivipary in Zea mays L. Planta. 171:358-364.

Radin, J.W. and R.C. Ackerson. 1981. Water relations of cotton plants under nitrogen deficiency. III. Stomatal conductance, photosynthesis and abscisic acid accumulation during drought. Plant Physiol. 67:115-119.

Radin, J.W., L.L. Parker, and G. Guinn. 1982. Water relations of cotton plants under nitrogen deficiency. V. Environmental control of abscisic acid accumulation and stomatal sensitivity to abscisic acid. Plant Physiol. 70:1066-1070.

Raschke, K., M. Pierce, and C.C. Popiela. 1976. Abscisic acid content and stomatal sensitivity to $\mathrm{CO}_{2}$ in leaves of Xanthium strumarium $\mathrm{L}$. after pretreatments in warm and cold growth chambers. Plant Physiol. 57:115121.

Robichaud, C. and I.M. Sussex. 1986. The response of viviparous-1 and wild-type embryos of Zea mays to culture in the presence of abscisic acid. J. Plant Physiol. 126:235-242.

Shaybany, B. and G.C. Martin, 1977. Abscisic acid identification and its quantitation in leaves of Juglans seedlings during waterlogging. J. Amer. Soc. Hort. Sci. 102:300-302.

Smith, J.D., F. Fong, M.K. Walker-Simmons, and J.L. Ried. 1993. Classification and characterization of the viviparous mutants of maize (Zea mays L.). Proc. 6th Intl. Symp. Preharvest sprouting in cereals, Coeur d'Alene, Idaho. p. 295-302.

Sodek. L., P.J. Lea, and B.J. Miflin: 1980. Distribution and properties of a potassium dependent asparaginase isolated from developing seeds of Pisum sativum and other plants. Plant Physiol. 65:22-26.

White, C.N., W.R. Proebsting, and C.J. Rivin. 1996. GA signalling in the developing embryo: Evidence for a GA/ABA balance governing vivipary and maturation. Maize Genet. Coop. Nwslt. 70:19-20.

Yamaguchi, M., G.C. Hanna, J.M. Ogawa, F.D. Howard, and B. Weir. 1967. Seed sprouting in canning tomato fruits. Calif. Agr. 21:11.

Yomo, H. and J.E. Varner. 1973. Control of the formation of amylases and proteases in the cotyledons of germinating peas. Plant Physiol. 51:708713. 